\title{
The making of oncology: The trinity of true carcinogenic worms
}

\author{
K. Lalchhandama
}

Department of Zoology, Pachhunga University College, Aizawl 796oor, Mizoram, India

\begin{abstract}
Three flukes, Schistosoma haematobium (urinary blood fluke), Clonorchis sinensis (Chinese liver fluke), and Opisthorchis viverrini (Southeast Asian liver fluke) are, by official decree, Group 1 (fully proven) human carcinogens. Thus, they comprise a group of preventable carcinogens. But considering the situation of prevailing infection, from the lifestyle and food habits of people in the endemic regions, it is unlikely that they are eradicated in the near future. S. haematobium is transmitted by snails and infection is acquired from snail-infested water. C. sinensis and $O$. viverrini are both transmitted from eating fish. As medically important flukes, it is crucial to understand their biology, and this is an attempt to explain that in the light of the history of their discovery. Further, this is written with a hope that several facts, often erroneously presented in scientific literature, about these flukes are rectified.
\end{abstract}

Key words: Clonorchis sinensis; Opisthorchis viverrini; Schistosoma haematobium; fish, host life cycle, snail.
Received 6 March 2017 Accepted 25 March 2017

*For correspondence $\bowtie$ chhandama@pucollege.edu.in

\section{Urinary Blood Fluke}

Schistosoma haematobium Weinland, 1858 (originally Distomum haematobium Bilharz, 1851), is the only species of fluke that inhabits the urinary tract of humans. It is found in the Middle East, India, Turkey, North Africa and subSaharan Africa. All species of Schistosoma are very similar in structure and pathological behaviour. As member of Schistosoma, an adult worm is monoecious, but with distinct male and female bodies; hence, it has a split body (Figure 1). In fact, the generic name is a combination of Greek words $\sigma x i \sigma \mu \alpha$, (schisma) meaning split, and $\sigma \tilde{\omega} \mu \alpha$ (sôma) meaning body. The adult male and female pair lives as an individual in copula (bonded pair). The male forms the flatworm part, measuring $10-18 \mathrm{~mm}$ in length and $1 \mathrm{~mm}$ in width. It bears oral and ventral suckers towards its anterior end. Its leaf-like flat body is curled up from both sides to form a channel or groove called gynaecophoric canal in which the female is wrapped up. Thus, it gives the general appearance of a cylindrical roundworm body. Only the extreme anterior and posterior ends of the female are exposed. In contrast to the male, a female exhibits every feature of a roundworm. It is cylindrical and elongated, measuring about $20 \mathrm{~mm}$ in length and $0.25 \mathrm{~mm}$ in width. Its pathogenic armament, the eggs are oval-shaped, measuring $144 \times 58 \mu \mathrm{m}$ in diameter, with characteristic terminal spine (Figure 2). This is an important diagnostic tool because co-infection 


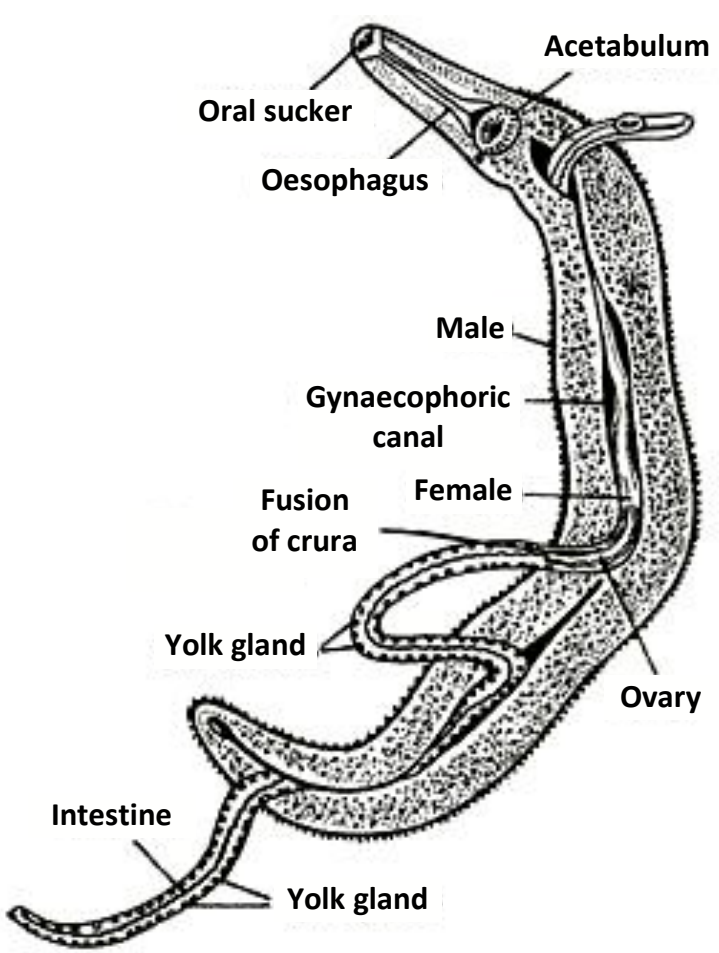

Figure 1 | Adult S. haematobium. A larger male encloses the smaller roundworm-like female.

with S. mansoni (having a lateral-spined eggs) is common. ${ }^{[1]}$

The miracidium (from the Greek word $\mu \varepsilon\llcorner\rho \alpha ́ k\llcorner o v$, meirakion, meaning youth) is also pear-shaped, and gradually elongates as it ages. It measures about $136 \mu \mathrm{m}$ long and $55 \mu \mathrm{m}$ wide. The body is covered by anucleate epidermal plates separated by epidermal ridges. The epidermal cells give off numerous hair-like cilia on the body surface. Epidermal plate is absent only at the extreme anterior called apical papilla, or terebratorium, which contains numerous sensory organelles. Unlike other flukes, schistosomes do not possess sensory organs called eyespots. The most prominent organs are an apical gland and a pair of penetration glands, both of which open near the terebratorium. The rest of its internal body is almost fully filled with glycogen particles and vesicles. ${ }^{[2]}$

The ceraria has a characteristic bifurcated tail, classically called furcae (Latin for fork);

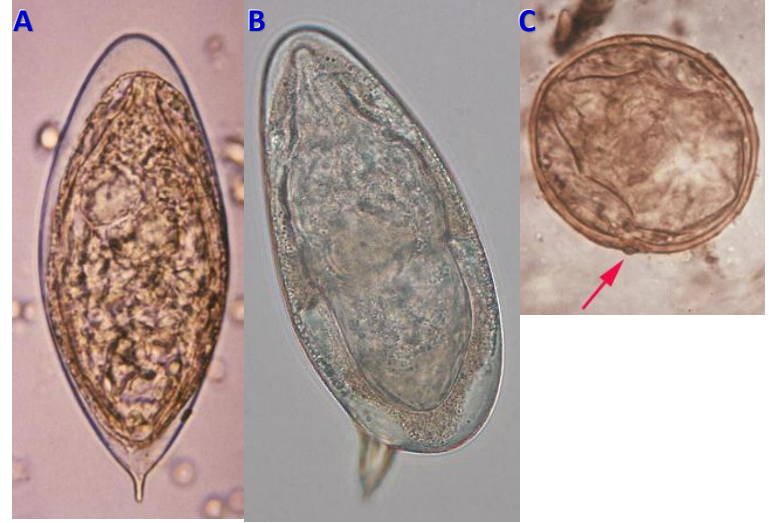

Figure 2 | Comparison of schistosome eggs. (A) S. haematobium with terminal spine, (B) S. mansoni with lateral spine, and (C) S. japonicum with spherical shape and minute lateral spine (arrow head).

hence, the name (derived from a Greek word ке́ркоS, kerkos, meaning tail). The tail is about $0.2 \mathrm{~mm}$ long and $47 \mu \mathrm{m}$ wide, somewhat loosely attached to the main body. The body is pearshaped and measures $0.24 \mathrm{~mm}$ in length and 0.1 $\mathrm{mm}$ in width. ${ }^{[3]}$ Its tegument is fully covered with spine. A conspicuous oral sucker is at the apex. As a non-feeding larva, there are no elaborate digestive organs, only oesophagus is distinct. There are three pairs of mucin glands connected to laterally to the oral sucker at the region of the ventral sucker. ${ }^{[4][5]}$

\section{Life cycle}

While other schistosomes release their eggs in the intestines to be excreted along with the faeces, S. haematobium release their eggs in the urinary tract and excrete along with the urine. ${ }^{[6]}$ Then the rest is quite similar (Figure 3). The eggs can only survive in stagnant freshwater. In a good water condition, an osmotic pressure stimulates the eggs to hatch within 15 minutes into miracidia. Using their cilia, the miracidia actively swims searching for an intermediate host-snail. They must act fast because if they fail to find a snail within 24-28 hours, their food (glycogen) reserve runs out and will die. Species of snail belonging to the genus Bulinus, including B. globosus, B. forskalii, B. nyassanus, and B. trunca- 


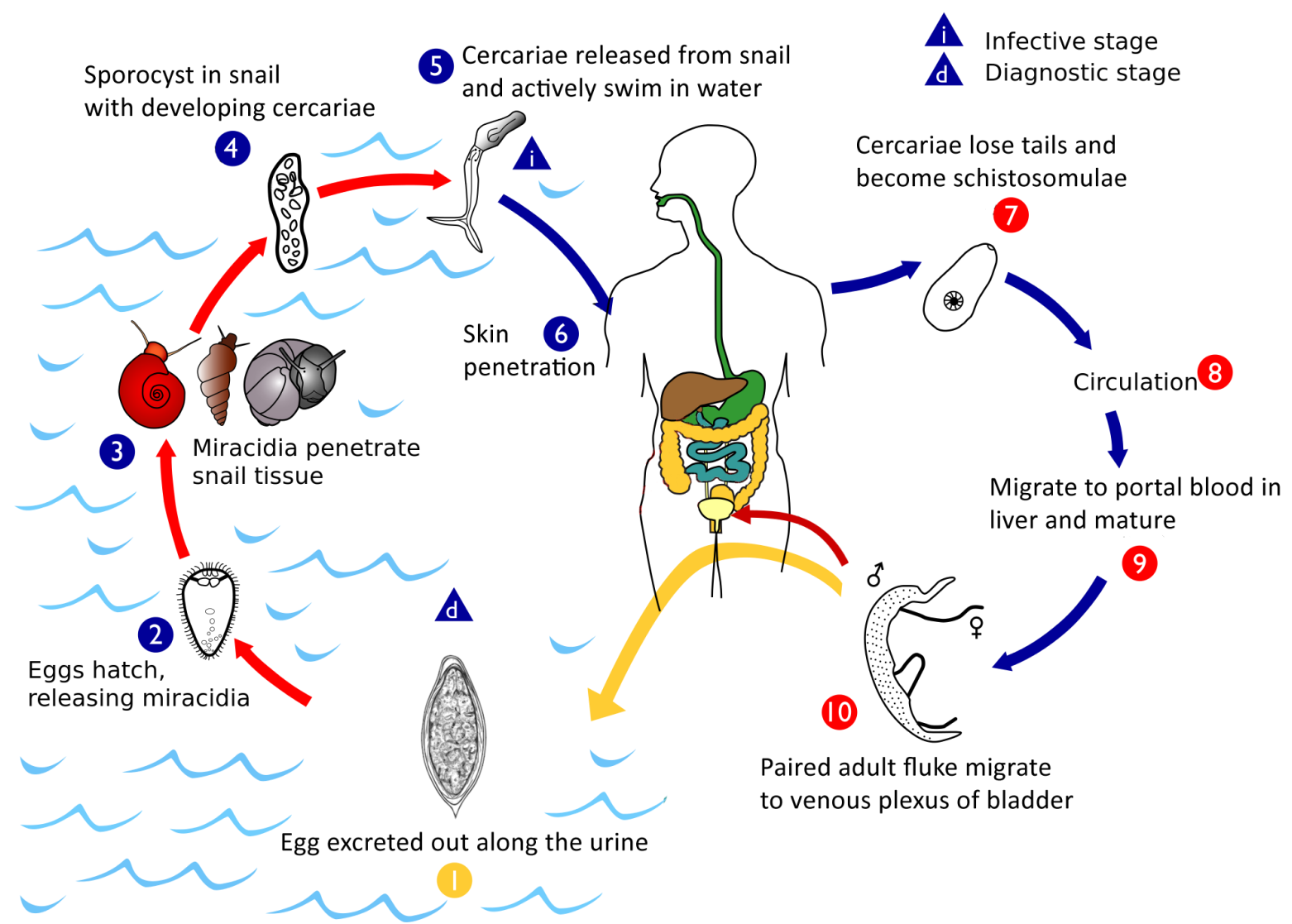

Figure 3 | Life cycle of S. haematobium. (Adapted from https://www.cdc.gov/parasites/schistosomiasis/ biology.html)

tus, can harbour the miracidia. The miracidia simply pierce through the soft skin of the snail and move to the liver. In the snail tissue, they lost their cilia and extra-epithelial covering within 24 hours. Then they transform into sporocysts that undergo active cell division after two weeks. The mother sporocyst produces many daughter sporocysts. Each daughter sporocyst gives rise to new fork-tailed larvae called cercariae. After a month, the sporocysts rupture liberating free cercariae, which leave the liver and penetrate out of the snail into water. From one mother sporocyst, half a million cercariae are produced. Each cercaria has a biforked tail with which it swims to find a human host. Again the cercariae are short lived and can survive in water for 4-6 days unless they find a human host. ${ }^{[7]}$
When human comes in contact with an infested water, most commonly during bathing, the cercariae attach themselves on the skin using their suckers. After proper orientation, they start piercing the skin by secreting proteolytic enzymes that widen the skin pores. This process takes about 3-5 minutes and produces itching, but by then, they have penetrated the skin. Their tails are dislodged during the penetration such that only the head parts enter. They continue the piercing process until they enter the blood vessels. They are now known as schisotomulae. They enter the systemic system to reach the heart and then the liver, and along the way many are killed by the immune cells. Survivors enter the liver within 24 hours. From the liver they enter the portal vein to reach different parts of the body. Unlike other species again, the 
schistosomulae of S. haematobium reach the vesical vessels through anastomotic channels between radicles of the inferior mesenteric vein and pelvic veins. After living inside small venules in the submucosa and wall of the bladder, they migrate to the perivesical venous plexus (a group of veins at the lower portion of the bladder) to attain full maturation. ${ }^{[8]}$

Individuals sort out opposite sexes. The female body becomes enveloped within the rolledup gynaecophoric canal of the male; thus, becoming partners for life. Sexual maturation is attained after 4-6 weeks of initial infection. A female generally lays 500-1,000 eggs in a day. ${ }^{[7]}$ The female only leaves the male briefly for laying eggs. It has to because only it can enter the small and narrow peripheral venule in the submucosa so that the eggs can be released into the bladder. The embryonated eggs penetrate the bladder mucosa using proteolytic enzymes, aided by their terminal spines and by the contraction of the bladder. The enzyme is a toxin specifically for damaging (necrosis) the tissue. Under normal situation, the eggs released into the bladder do not cause pathological symptoms. But eggs often fail to penetrate the bladder mucosa and remain trapped in the bladder wall; it is these which produce the lesions by releasing their antigens and provoking granuloma formation. Granulomata in turn coalesce to form tubercles, nodules or masses that often ulcerate. This is the condition behind the pathological lesions found in the bladder wall, ureter and renal; and also tumour, both benign and malignant. ${ }^{[9][10]}$ The fluke continouosly lays eggs throughout their life. An average lifespan is 3-4 years. ${ }^{[11]}$

\section{The Chinese (Oriental) Liver Fluke}

Clonorchis sinensis Looss, 1907 (originally Distoma sinense Cobbold, 1875), is a hermaphrodite fluke, housing complete male and female reproductive systems in one body (Figure 4). An adult fluke is leaf-shaped, dorso-ventrally flat, transparent, and measures about 10-22 $\mathrm{mm}$ long and $3.5 \mathrm{~mm}$ wide. ${ }^{[12]}$ It is obtusely elongated with a round posterior. It tapers gradually towards the

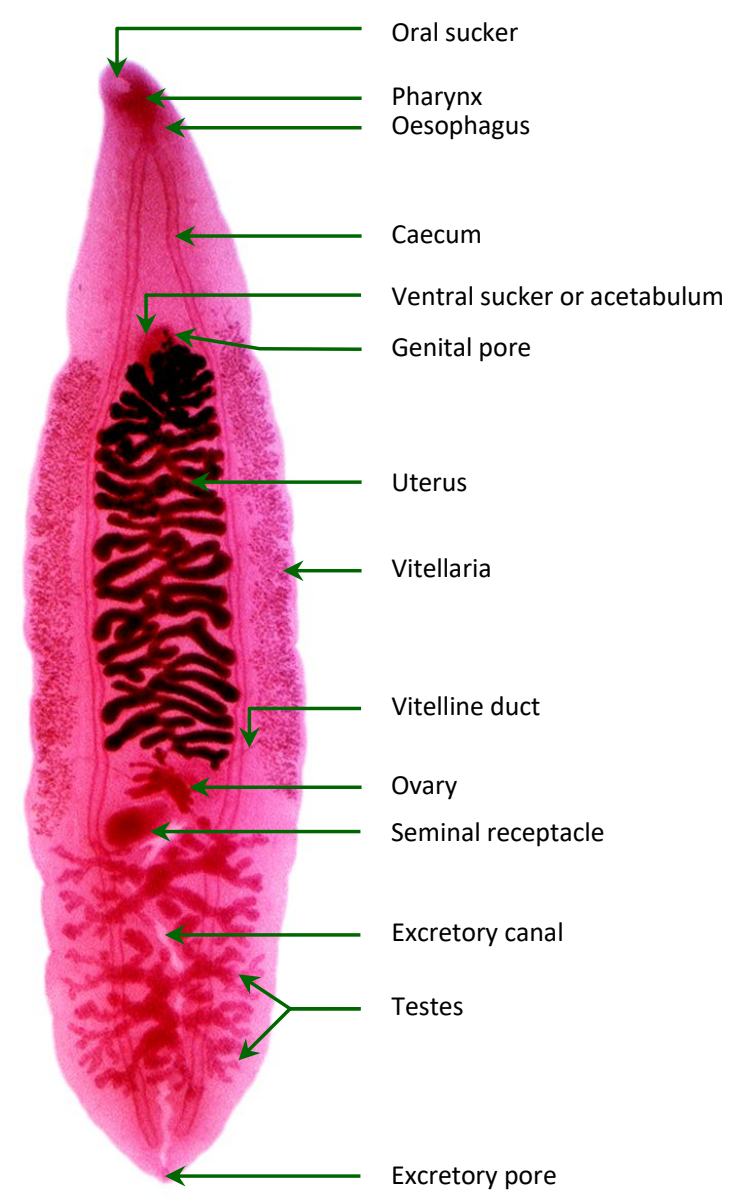

Figure 4 | Adult C. sinensis. (From Sripa et al. (2007). PLoS Medicine 4(7): e201. doi:10.1371/ journal.pmed.0040201) CC-BY-2.5

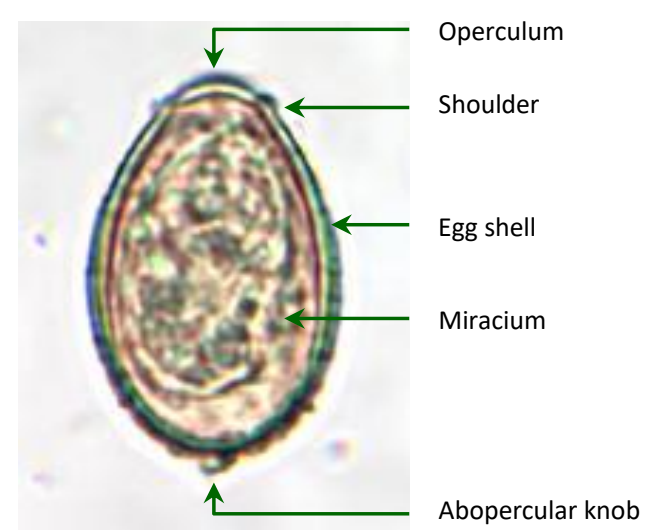

Figure 5 | Egg of $\boldsymbol{C}$. sinensis. $\times 400$ (https:// www.cdc.gov/dpdx/clonorchiasis/index.html) 
anterior end, which terminates with a circular opening called oral sucker, which acts as both the mouth and a holdfast organ. The mouth leads to a short pharynx, which in turn opens into oesophagus. Its brain (central nervous system) consists of two cerebral ganglia attached behind the pharynx. A transverse commissure connects the two ganglia. There are four pairs of nerves projecting anteriorly and three pairs posteriorly from each ganglion. The anterior nerves contribute to the pharynx and to the formation of the circum-oral ring around the oral sucker. The posterior nerves contribute to the innervation of the ventral sucker, the gut, the reproductive organs and the excretory bladder ${ }^{[13]}$ The oesophagus bifurcates and extends into two intestinal caeca, running on both sides throughout the length of body, and open into a common excretory pore at the posterior end. A small ventral sucker (or acetabulum) lies at about onefourth of the body length form the oral sucker. A common genital pore opens just in front of it. The long and folded tube of uterus is the most distinct reproductive organ, running from the genital pore up to the ovary. A single rounded ovary lies slightly posterior to the centre of the body. The uterus and seminal ducts from the testes meet and opens at the genital pore. There are two testes towards the posterior end, one in front, and one behind. They are highly branched (dendritic). The yolk factory, vitellaria (or vitelline glands) are distributed on either side of the body. ${ }^{[14][15][16]}$

The eggs are similar to those of other related flukes such as Opisthorchis viverrini and O. felineus, and are often confused during diagnosis. They are small and oval in shape, measuring about $30 \times 15 \mu \mathrm{m}$ in diameter (Figure 5). They are sharply curved and with a clear convex operculum (lid-like structure) towards the narrower end. At the broader end is a stem-shaped abopercular knob. The larva called miracidium can be seen inside the fertilised egg. ${ }^{[17]}$ In contrast to schistosomes and other flukes, there is no freeliving miracidium for $\mathrm{C}$. sinensis. There is also formation of a worm-like rediae (named after the 17th-century Italian physician Francesco Redi). Further, the cercaria is structurally dis- tinct, having an unforked tail with a fin fold, eyespots, excretory canal, rudimentary acetabulum, and oral hooks. ${ }^{[18][19]}$

\section{Life cycle}

C. sinensis exhibits a complex life cycle, requiring three different hosts-fish-eating mammals including humans as the definitive hosts, snails as the first intermediate hosts, and cyprinid fish as the second intermediate hosts (Figure 6). Living in the human bile duct, the flukes release their eggs through the biliary tract, and are passed into the intestine. From there the eggs are excreted out along with the faeces. The fully-developed miracidium is visible inside the egg. ${ }^{[17]}$ In contrast to other flukes in which the miracidia hatch in water bodies and swim in water to penetrate the body of a suitable host, the eggs of $C$. sinensis are simply deposited in water. Eggs remain viable for more than three months in an external environment. The eggs are then eaten up by snails. ${ }^{[16]} \mathrm{A}$ number of freshwater snails can harbour the first larvae, including Alocinma longicornis, Bithynia longicornis, B. fuchsiana, B. misella, Parafossarulus manchouricus, P. anomalospiralis, Melanoides tuberculata, Semisulcospira cancellata, S. amurensis, $S$. libertina, Assiminea lutea and Melanoides tuberculata. ${ }^{[20 \mid[21]}$

Upon reaching the snail's stomach, the embryonic membrane is dissolved by the snail's digestive enzymes that facilitate the miracidium to hatch within one hour. The cilia-covered miracidium can move about, penetrating the intestine, enters the haemocoel and digestive gland. Here, it undergoes metamorphosis into a sporocyst within four hours of infection. For three weeks, the sporocyst divides to give rise to numerous smaller larvae, 20 to 50 in number, called rediae. Each redia produces nearly 50 larvae called cercariae.[22] The mature cercariae break out of the redia and actively bore out of the snail body into the freshwater environment. But they are non-feeding and must find a fish host within 2-3 days till their glycogen reserve last, otherwise they die. ${ }^{[16]}$

The cercariae of $C$. sinensis are different from those of other flukes in that they do not actively 
swim. Instead, they initially hang upside-down in the water, and then sink to the bottom. They swim to the water surface to resume their initial position, and the movement is repeated in cycle. When there is any disturbance in the immediate surrounding by a fish, then they start to attack. They attached themselves on the fish scales using their suckers. More than 100 freshwater cyprinid fish act as second intermediate hosts, including common carp (Cyprinus carpio), grass carp (Ctenopharyngodon idellus), crucian carp (Carassius carassius), goldfish (Carassius auratus), pond smelt (Hypomesus olidus), etc. ${ }^{23}[24]$ Boring their way into the fish body, the cercariae reach the muscle within 6 to 13 minutes. They cast off their tails while penetrating, and start secreting a viscous fluid over their bodies. Within an hour of penetration, the fluid secretion gradually hardens to become the cysts. Encystment is actually a sequential process: after 18-23 hours a transparent vacuole (the vacuolation process) surrounds the body, the vacuole is replaced by an opaque layer that forms the primary cyst layer; the outer secondary cyst layer is formed as result of local tissue interaction with the host. This protective cyst proves useful when the fish muscle is consumed by a host. The fully encysted larvae are oval-shaped and are called metacercariae and are infective to the final hosts after 45 days. ${ }^{[15]}$

The definitive host acquires the metacercariae from eating raw or undercooked fish. Fish

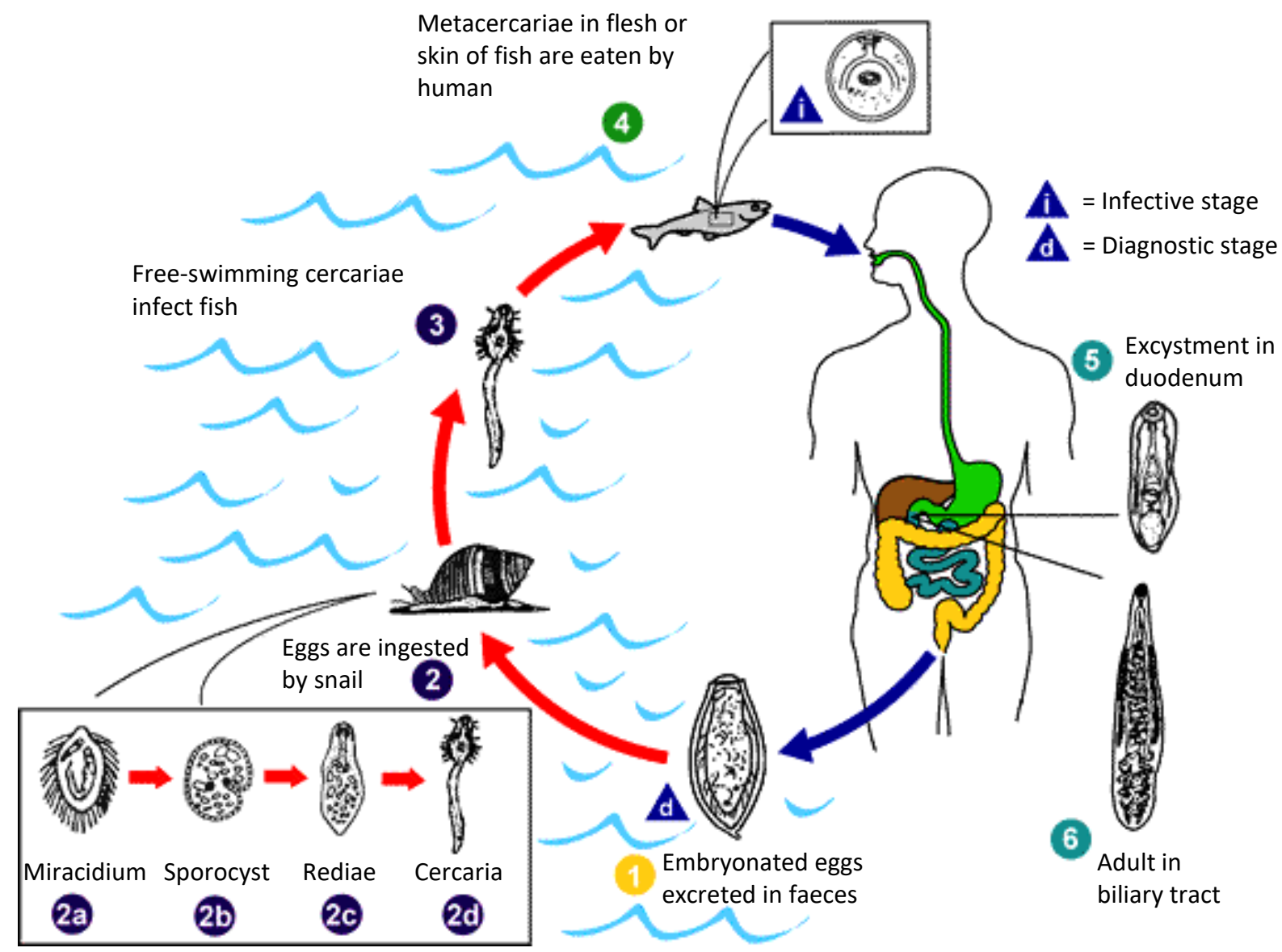

Figure 6 | General life cycle of $\boldsymbol{C}$. sinensis/O. viverrini. (Adapted from https://www.cdc.gov/parasites/clonorchis/ biology.html) 
-eating animals constitute the cohort of definitive hots, including mammals such as humans, cats, rats, dogs, pigs, tigers, civets, and camels; as well as birds, such as night heron. Unlike most flukes in which the cysts of the metacercariae are digested by the host's digestive enzymes to liberate the metacercariae, $C$. sinensis metacercariae simply burst up the cysts by their own effort in the lumen of the small intestine. The larvae can be seen in the cyst to make rotary movements, and during excystment they creep about in a leech-like fashion using their suckers. This is facilitated by a raise in temperature. ${ }^{[25 \mid[26]}$ Again in contrast to most helminth parasites, $C$. sinensis larvae do not penetrate the intestinal lumen to invade other organs, but instead travel through the common bile duct from the duodenum. ${ }^{[27]}$ They get attached to the mu-

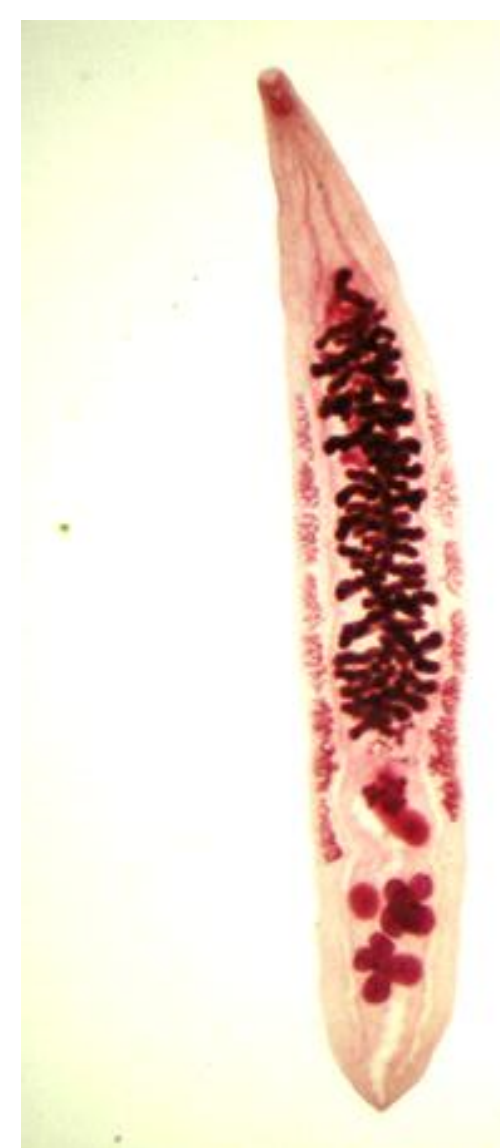

Figure 7 | Adult O. viverrini. (https://www.cdc.gov/ dpdx/opisthorchiasis/index.html) cosal wall using their suckers, and find their way towards the opening of the common bile duct. Within six hours, they occupy the bile duct, ${ }^{[28]}$ and by 48 hours all have migrated into the biliary tree. The natural habitats are mainly the hepatic ducts, some lodge in the gall bladder, and rarely they occur in the pancreas and duodenum. They feed on the secretions from the mucosa of the bile duct. ${ }^{|29|}$ They become sexually mature in 26 days and start laying eggs. ${ }^{[26]}$ As a monoecious species, they reproduce by selffertilisation. An individual fluke can produce 4,000 eggs in a day. ${ }^{[30]}$ The average lifespan of an adult is 30 years. ${ }^{[15[31]}$

\section{The Southeast Asian Liver Fluke}

O. viverrini Poirier, 1886, resembles C. sinensis and $O$. felineus in most aspects. The principal differences are smaller size $(7 \mathrm{~mm}$ long and 1.5 mm wide) and lobed testes (Figure 7), which are highly branched (dendritic) particularly in $C$. sinensis (compare with Figure 4) ${ }^{[32 \mid[33]}$ The first diagnostic distinction was worked out by Robert Thomson Leiper in 1915. ${ }^{[34]}$

Eggs of 0 . viverrini measures $26.7 \mu \mathrm{m}$ in length and $15 \mu \mathrm{m}$ in width, and have welldeveloped operculum of about 5-6 $\mu \mathrm{m}$ in diameter. The miracidium is pear-shaped, $32 \mu \mathrm{m}$ long and $17 \mu \mathrm{m}$ wide. A mature sporocyst is $1.1 \mu \mathrm{m}$ long and $0.65 \mu \mathrm{m}$ wide. ${ }^{[35]}$ Redia is elongated, up to $0.8 \mathrm{~mm}$, sausage-shaped, narrow, and saclike. The tegument of the anterior part is covered with dense microvilli, and the rest is covered with reticular structure. An oral aperture opens at the anterior end. ${ }^{[36]}$ There are 15 developing ceraciae inside each redia. ${ }^{[35]}$

The cercaria is $532 \mu \mathrm{m}$ long. Its body is about 100-250 $\mu \mathrm{m}$ long and 33-68 $\mu \mathrm{m}$ wide. The body surface is covered with numerous minute spines and has seven pairs of sensory hairs on either side. An oral sucker is well developed but a ventral sucker is rudimentary. A pharynx is flanked by two eyespots. There are seven pairs of penetrating gland cells occupying the central region. An excretory channel is present at the posterior end. The tail is approximately double the length of the body, measuring $360-475 \mu \mathrm{m}$. It is $16-29$ 
$\mu \mathrm{m}$ wide and is provided with lateral fins. A caudal excretory tube runs along the centre of the

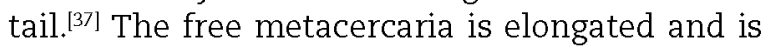
320-820 $\mu \mathrm{m}$ long and 100-140 $\mu \mathrm{m}$ wide. The entire body, excluding the area around suckers and posterior extremity, is armed with spines. Oral and ventral suckers are prominently developed. [36]

\section{Life cycle}

o. viverrini follows the general pattern of development and transmission as that of $\mathrm{C}$. sinensis. But the first intermediate hosts are freshwater snails belonging to the species complex of Bithynia siamensis, in which the eggs hatch. Development in the snail takes about 8 to 10 weeks, and the complete life cycle lasts for 4-4.5 months. ${ }^{[35]}$ There are about 20 species of fish that can act as second intermediate hosts. ${ }^{[38][39]}$ In the definitive host, the adult flukes inhabit the bile duct, gall bladder, and sometimes the pancreatic duct. Despite being hermaphrodites, they preferentially reproduce by crossfertilisation (two individuals exchange their gametes) ${ }^{[33]}$ An individual fluke may lay as many as 3,160 eggs in a day (the number is 2,830 in cats, and 2,353 in rabbits), ${ }^{[40]}$ with the number ranging from $2,000-4,000 .[41]$ The exact lifespan is not known, but is estimated to be more than 25 years. ${ }^{[42]}$

\section{References}

I. Hutchison, H.S. (1928). The pathology of bilharziasis. The American Journal of Pathology. 4 (I): I-I6.

2. Cort, W.W. (1919). Notes on the eggs and miracidia of the human schistosomes. University of California Publications in Zoology. I8 (I8): 509-519.

3. Faust, E.C. (1919). Notes on South African cercariae. The Journal of Parasitology. 5 (4): 164-175.

4. Faust, C.E. (1920). Criteria for the differentiation of schistosome larvae. The Journal of Parasitology. 6 (4): 192-194.

5. Mohammed, A.S. (193I). The secretory glands of the cercariae of S. Haematobium and S. Mansoni from
Egypt. Annals of Tropical Medicine ES Parasitology. 26 (I): 7-22. doi:10.1080/00034983.1932.11684702

6. Leiper, R.T. (1915). Report on the results of the Bilharzia Mission in Egypt, 1915. Journal of the Royal Army Medical Corps. 25 (2): I-55, 147-192.

7. Akl, M.M. (2009). Bilharziasis: A Granulomatous Parasitic Disorder with Grave Implications. In Mansourian, B.P.; Wojtczak, A.; Sayers, B.M. Medical Sciences - Volume I. Oxford (UK): Eolss Publishers Co. Ltd. pp. 374400. ISBN 978-I-84826-733-6

8. Dew, H.R. (1923). Observations on the pathology of schistosomiasis ( $S$. haematobium and $S$. mansoni) in the human subject. The Journal of Pathology and Bacteriology. 26 (I): 27-39. doi:I0.1002/path.I700260104

9. Mills, E.A.; Machattie, C.; Chadwick, C.R. (1936). Schistosoma haematobium and its life cycle in Iraq. Transactions of the Royal Society of Tropical Medicine and Hygiene. 30 (3): 317-334. doi:10.1016/Soo35-9203(36)900688

Io. Ibrahim, H. (1948). Bilharziasis and bilharzial cancer of the bladder. Annals of the Royal College of Surgeons of England. 2 (3): 129-I4I.

II. Wilkins, H.A.; Goll, P.H.; de C. Marshall, T.F.; Moore, P.J. (1984). Dynamics of Schistosoma haematobium infection in a Gambian community. III. Acquisition and loss of infection. Transactions of the Royal Society of Tropical Medicine and Hygiene. 78 (2): 227-232. doi:10.1016/0035-9203(84)90283-9

I2. Kim, T.S.; Pak, J.H.; Kim, J.B.; Bahk, Y.Y. (2016). Clonorchis sinensis, an oriental liver fluke, as a human biological agent of cholangiocarcinoma: a brief review. $B M B$ Reports. 49 (II): 590-597. doi:I0.5483/ BMBRep.2016.49.II.IO9

13. He, Y.X. (1991). Nervous system of Clonorchis sinensis as revealed by acetylcholinesterase activity. The Southeast Asian Journal of Tropical Medicine and Public Health. $22(3): 4 \mathrm{I} 2-4 \mathrm{I} 6$.

14. Ijima, I. (1887). Notes on Distoma endemicum, Baelz. The Journal of the Science College of the Imperial University. I (I): 47-59.

15. Adams, A.M. (2006). Foodborne trematodes. In Ortega, Y. R. Foodborne Parasites. New York: Springer Science+Business Media. pp. I68-I73. ISBN 978-0-387$31197-5$

16. Bogitsh, B.J.; Carter, C.E; Oeltmann, T.N. (2005). Hu- 
man Parasitology (3 ed.). Amsterdam (Netherlands): Elsevier Academic Press. pp. 207-210. ISBN 978-0-I2o88468-I

17. Ridley, J.W. (2012). Parasitology for Medical and Clinical Laboratory Professionals. Clifton Park, N.Y.: Delmar. pp. I87-I88. ISBN 978-I-4-3544816-2

18. Faust, E.C. (1930). Larval flukes associated with the cercariae of Clonorchis sinensis in bithynoid snails in China and adjacent territory. Parasitology. 22 (2): I45-I55. doi:Io.IOI7/Soo3II82000oIIO2I

19. Price, E.W. (1940). A review of the trematode superfamily Opisthorchidae. Proceedings of the Helminthological Society of $W$ ashington. 7 (I): I-I3.

2o. Hung, Ng.; Dung, D.; Lan Anh, Ng.; Van, P.; Thanh, B.; Van Ha, Ng.; Van Hien, H.; Canh, L. (2015). Current status of fish-borne zoonotic trematode infections in Gia Vien district, Ninh Binh province, Vietnam. Parasites EG Vectors. 8 (I): 2I. doi:Io.II86/s1307I-0I5-0643-6

2I. Tang, Z-L.; Huang, Y.; Yu, X-B. (2016). Current status and perspectives of Clonorchis sinensis and clonorchiasis: epidemiology, pathogenesis, omics, prevention and control. Infectious Diseases of Poverty. S (I): 7I. doi:IO.II86/s40249-oI6-oI66-I

22. Hong, S-T; Fang, Y (2012). Clonorchis sinensis and clonorchiasis, an update. Parasitology International. 6I (I): I7-24. doi:Io.IoI6/j.parint.20II.06.007.

23. Chai, J-Y.; Darwin Murrell, K.; Lymbery, A. J. (2005). Fish-borne parasitic zoonoses: Status and issues. International Journal for Parasitology. 35 (II-I2): I233-I254. doi:Io.IoI6/j.ijpara.2005.07.013

24. Sohn, Woon-Mok (2009). Fish-borne zoonotic trematode metacercariae in the Republic of Korea. The Korean Journal of Parasitology. 47 (Suppl): $\mathrm{SIO}_{3}-\mathrm{II} 3$. doi:I0.3347/kjp.2009.47.S.Sio3

25. Kobayashi, H. (1915). On the life-history and morphology of Clonorchis sinensis. Zentralblatt für Bakteriologie, Parasitenkunde, Infektionskrankbeiten und Hygiene. 75 (4): 299-318.

26. Kobayashi, H. (1917). On the life-history and morphology of the liver distome Clonorchis sinensis. Mitteilungen aus der Medizinischen Fachschule zu Keijo. I: 25I284.

27. Sun, T.; Chou, S.T.; Gibson, J.B. (1968). Route of entry of Clonorchis sinensis to the mammalian liver. Experimental Parasitology. 22 (3): 346-35I. doi:Io.IoI6/oor4-
4894(68) 9 OIII-2

28. Mukoyama, T. (192I). Experimental studies on the route of migration by Clonorchis sinensis in the final host. Nippon Byori Gakkai Kaishi. In: 443.

29. Faust, E. C.; Khaw, O. K. (1925). Excystment phenomena in Clonorchis sinensis. Experimental Biology and Medicine. 23 (3): 245-248. doi:10.318I/o0379727-23-2916

3o. Kim, J-H.; Choi, M-H.; Bae, Y.M.; Oh, J-K.; Lim, M.Ky.; Hong, S-T.; Ito, A (20II). Correlation between discharged worms and fecal egg counts in human clonorchiasis. PLoS Neglected Tropical Diseases. S (го): eI339. doi:Io.I37I/journal.pntd.ooor339

31. Qian, M.-B.; Utzinger, J.; Keiser, J.; Zhou, X.-N. (2016). Clonorchiasis. The Lancet. 387 (I0020): 80o-810. doi:Io.IoI6/Sor40-6736(15)60313-0

32. Muller, R.; Wakelin, D. (2002). Worms and Human Disease (2 ed.). Wallingford (UK): CABI. pp. 43-44. ISBN 978-0-85-199516-8

33. Sithithaworn, P.; Andrews, R.; Shekhovtsov, S.V.; Mordvinov, V.A.; Furman, D.P. (2014). Opisthorchis viverrini and Opisthorchis felineus. In Motarjemi, Y.; Moy, G.; Todd, E. Encyclopedia of Food Safety. San Diego (US): Academic Press. pp. I70-178. ISBN 978-oI2-3786I3-5

34. Leiper, E.T. (1915). Notes of the occurrence of parasites presumably rare in man. Journal of the Royal Army Medical Corps. 24 (6): 569-575. doi:10.1136/jramc-24-o6o7

35. Upatham, E.S. (1988). A review of experimental and field research on the human liver fluke, Opisthorchis viverrini. Journal of The Science Society of Thailand. I4: 245-262.

36. Scholz, T.; Ditrich, O.; Giboda, M. (2016). Study on the surface morphology of the developmental stages of the liver fluke, Opisthorchis viverrini (Trematoda: Opisthorchiidae). Annales de Parasitologie Humaine et Comparée. 67 (3): 82-90. doi:Io.Io51/parasite/199267382

37. Ito, J. (1962). Studies on cercariae from fresh water snails in Thailand. Japanese Journal of Medical Science EF Biology. 15: 249-270.

38. Wykoff, D.E.; Harnisuta, C.; Juttijudata, P.; Winn, M.M. (1965). Opisthorchis viverrini in Thailand-the life cycle and comparison with $O$. felineus. The Journal of Parasitology. 5I: 207-214. doi: 10.2307/3276083 
39. Rim, H.J.; Sohn, W.M.; Yong, T.S.; Eom, K.S.; Chai, J.Y.; Min, D.Y.; Lee, S.H.; Hoang, E.H.; Phommasack, B.; Insisengmay, S. (2008). Fishborne trematode metacercariae detected in freshwater fish from Vientiane Municipality and Savannakhet Province, Lao PDR. The Korean Journal of Parasitology. 46 (4): 253-26o. doi:I0.3347/kjp.2008.46.4.253

40. Wykoff, D. E.; Ariyaprakai, K. (1966). Opisthorchis viverrini in Thailand-egg production in man and laboratory animals. The Journal of Parasitology. 52 (4): 63I. doi:10.2307/3276418
4I. Feldmeier, H.; Hazay, M.; Sato, M.; Tiengkham, P.; Nishimoto, F.; Jiang, H.; Sopraseuth, V.; Moji, K. (2016). Morbidity assessment of Opisthorchis viverrini infection in rural Laos: I. Parasitological, clinical, ultrasonographical and biochemical findings. Tropical Medicine and Health. 44 (I): 12. doi:Io.I186/s41182-016-0oI2-y

42. Kaewpitoon, N.; Kaewpitoon, S. J.; Pengsaa, P.; Sripa, B. (2008). Opisthorchis viverrini: the carcinogenic human liver fluke. World Journal of Gastroenterology. I4 (5): 666-674. doi:Io.3748/wjg.I4.666 